\title{
PELANTIHAN DAN PENGABDIAN MASYARAKAT KETERAMPIALAN MENULIS LONTAR
}

\author{
I Wayan Widiana \\ Jurusan PGSD, Fakultas Ilmu Pendidikan \\ Universitas Pendidikan Ganesha \\ Email: wayan_widiana@yahoo.co.id
}

\begin{abstract}
Abstrak
Dalam upaya menghapuskan kemiskinan dan mengurangi pengangguran yang ada di masyarakat sangat dibutuhkan suatu kesadaran dan motivasi yang sangat tinggi dari semua pihak, tidak hanya dari produsen tetapi juga dari pihak konsumen sebagai pengguna dan pemakai hasil Keterampilan Menulis Lontar. Pendidikan Kecakapan Hidup bertujuan untuk meningkatkan kualitas sumber daya manusia dengan memberikan latihan Keterampilan Menulis Lontar bagi warga masyarakat yang tidak bersekolah, kurang mampu dan miskin pengetahuan serta minimnya keterampilan yang dimilki sehingga nantinya dipakai sabagai bekal untuk membuka lapangan pekerjaan yang dapat meningkatkan tarap kehidupannya dengan lebih baik. Dalam upaya memberikan warga masyarakat yang membutuhkan keterampilan dan keahlian yang sangat bermanfaat sebagai sumber penghasilan serta mata pencaharian pokok sangat dipandang perlu dilaksanakan kursus dan pelatihan Keterampilan Menulis Lontar bagi warga masyarakat di Desa Tianyar Kecamatan Kubu Kab Karangasem, Bali. Metode yang digunakan dalam kegiatan ini adalah seminar dan workshop dengan melibatkan usia 15 sampai dengan 25 tahun yang masih produktif. Karya utama yang dihasilkan adalah (1) Masyarakat mendapatkan pengetahuan tentang cara Menulis Lontar yang baik. (2) masyarakat sudah mulai belajar menulis lontar di rumah mereka masingmasing secara mandiri. (3) Mengetahui cara penulisan lontar sehingga masyarakat bisa menulis dengan yang baik. (4) Mengetahui sistem pemasaran yang baik.(5) Masyarakat mulai berpikir kreatif, inovatif, dan terjun menjadi pengerajin menulis lontar.
\end{abstract}

Kata Kunci : Pelatihan, Keterampilan Menulis Lontar

\begin{abstract}
In attempt to erase poverty and reducing unemployment people in the society, it is very important to have a high self-awareness and motivation from the people, not only producer but also the consumers as the users of Lontar (Palm Leaves) Writing Skill result. The Life Skill Education is aiming the improvement of the human resources quality by giving Lontar Writing Skill training for people who don't have chance to have a formal education and those who have minimum knowledge and skill, so they can make their own work field which basically will make their life become better. In order to give those people an helpful skill that will make them having a better life, it's very important to give Lontar Writing Skill training for the society in Tianyar village, Kubu Sub district, Karangasem Regency. The method is used in this activity is seminar and workshop by involving 15 untill 25 years old productive people. The main product of this activity is (1) The society will be able to write lontar in a good way. (2) The society start to learn writing lontar at home by them self. (3) Knowing the lontar writing technique so that they can write it well. (4) Knowing the best marketing technique to use. (5) The society start to think creatively, innovatively, and to be a lontar writer.
\end{abstract}

Keywords: Training, Writing Lontar Skill 


\section{PENDAHULUAN}

Pendidikan Kecakapan Hidup (PKH) adalah program pelatihan yang telah diselenggarakan secara khusus oleh Desa/Kelurahan atau lembaga non formal yang ada dimasyarakat, untuk memberikan keterampilan bagi masyarakat pedesaan agar memperoleh pengetahuan, keterampilan dan menumbuh kembangkan sikap mental kreatif, inovatif, bertanggungjawab serta berani menanggung resiko ( sikap mental professional ). Dalam mengelola potensi diri dan lingkungannya yang dapat dijadikan bekal untuk meningkatkan kualitas hidupnya. Program Pendidikan Kecakapan Hidup ini sangat relevan dilaksanakan dipedesaan dalam rangka mengentaskan kemiskinan dan mengurangi pengangguran,yang sudah tentu melihat potensi yang ada serta disesuaikan dengan kondisi yang ada dalam masyarakat setempat.

$\begin{array}{crr}\text { Dalam } & \text { upaya } & \text { menghapuskan } \\ \text { kemiskinan } & \text { dan } & \text { mengurangi }\end{array}$ pengangguran yang ada di masyarakat sangat dibutuhkan suatu kesadaran dan motivasi yang sangat tinggi dari semua pihak, tidak hanya dari produsen tetapi juga dari pihak konsumen sebagai pengguna dan pemakai hasil Keterampilan Menulis Lontar.

Dalam upaya memberikan warga masyarakat yang membutuhkan keterampilan dan keahlian yang sangat bermanfaat sebagai sumber penghasilan serta mata pencaharian pokok sangat dipandang perlu dilaksanakan kursus dan pelatihan Keterampilan Menulis Lontar bagi warga masyarakat di Desa Tianyar Kecamatan Kubu Kab Karangasem, Bali.

Dana bantuan Pendidikan

Kecakapan Hidup dimanfaatkan untuk melatih masyarakat yang berminat/membutuhkan Keterampilan Menulis Lontar di Desa Tianyar Kecamatan Kubu Kab Karangasem. Dengan melihat perkembangan dan prospek kedepan dari pelatihan ini sangat memberikan arti bagi kehidupan masyarakat setempat. Hal ini juga terkait dengan prospek pohon kelapa yang sudah masuk didesa dan kegiatan pembuatan merupakan kebutuhan sekunder yang selalu membutuhkan keahlian yang profesional dan mampu memberikan pelayanan yang baik bagi masyarakat khususnya konsumen dan pemakai hasil Keterampilan Menulis Lontar seperti membuat keterampilan jadi bagi anak - anak, remaja dan orang dewasa maupun orang tua

Pelatihan Keterampilan Menulis Lontar merupakan peluang kerja pada masa sekarang dan yang akan datang karena merupakan salah satu sektor jasa yang tahan terhadap krisis ekonomi global. Bilamana krisis ekonomi melanda maka banyak tenaga produktif menjadi pengangguran, demikian juga banyak masyarakat yang kurang mampu khususnya anak - anak usia sekolah tidak melanjutkan pendidikannya Setelah diselenggarakan pelatihan keterampilan bagi warga masyarakat yang tidak bersekolah dan tidak bekerja. Dimana mereka berasal dari keluarga miskin usia 15 sampai dengan 25 tahun yang masih produktif pada masa sekarang merupakan peluang kerja baru dan dapat ditularkan kepada generasi berikutnya.

\section{SUMBER INSPIRASI}

Sumber inspirasi kegiatan Pelatihan Menulis Lontar ini adalah teridentifkasinya permasalahan yang dihadapi warga masyarakat di Desa Tianyar Kecamatan Kubu Kabupaten Karangasem yaitu upaya untuk menghapuskan kemiskinan dan mengurangi pengangguran, membuat masyarakat mampu berkarya dan menghasilkan produk yang berguna bagi kehidupan orang banyak, serta mampu menumbuhkan kesadaran dan kemampuan berwiraswasta yang mandiri, juga mampu bersaing dalam upaya menciptakan dan memperluas lapangan pekerjaan.

Berdasarkan identifikasi masalah tersebut, dengan mempertimbangkan keterbatasan waktu dan dana yang tersedia, disepakati antara tim Pelatihan Menulis Lontar dan mitra masalah yang diatasi melalui kegiatan ini adalah berkaitan dengan rendahnya kemampuan masyarakat dalam pelatihan penulisan lontar. Dilinnya kegiatan ini dimaksudkan 
untuk memberikan keterampilan kepada masyarakat dalam pelatihan menulis lontar.

\section{METODE}

Meode berkaitan dengan cara yang digunakan untuk memecahkan masalah. pemecahan masalah yang diterapkan dalam kegiatan pengabdian pada masyarakat pelaksanakan program yang meliputi : tahap persiapan, tahap pelaksanaan, dan tahap penilaian hasil belajar (Evaluasi) Pelaksanaan.

Berdasarkan tahapan di atas, adapun metode pelaksanaan kegiatan pengabdian pada masyarakat ini adalah menggunakan metode seminar dan workshop (pelatihan). Seminar berkaitan dengan pelatihan penulisan lontar.

\section{KARYA UTAMA}

Mengacu pada tujuan yang ditetapkan dalam kegiatan ini, karya utama yang dihasilkan yaitu sebanyak 6 orang sudah mampu membuka usaha sendiri di rumahnya sendiri. Di samping itu, sebagai dampak masyarakat juga mampu meningkatkan perekonomiannya masing-masing.

\section{ULASAN KARYA}

Pendidikan Kecakapan Hidup bagi Masyarakat Pedesaan dimaksudkan untuk memberikan pendidikan dan pelatihan khusus bagi masyarakat yang berdomosili di pedesaan yang jumlah penganggurannya cukup besar.

$\begin{array}{ccc}\text { Dalam upaya } & \text { menghapuskan } \\ \text { kemiskinan } & \text { dan } & \text { mengurangi }\end{array}$
pengangguran yang ada di masyarakat sangat dibutuhkan suatu kesadaran dan motivasi yang sangat tinggi dari semua pihak, tidak hanya dari produsen tetapi juga dari pihak konsumen sebagai pengguna dan pemakai hasil Keterampilan Menulis Lontar.

Proposal Pendidikan Kecakapan Hidup bertujuan untuk meningkatkan kualitas sumber daya manusia dengan memberikan latihan Keterampilan Menulis Lontar bagi warga masyarakat yang tidak bersekolah, kurang mampu dan miskin pengetahuan serta minimnya keterampilan yang dimilki sehingga nantinya dipakai sabagai bekal untuk membuka lapangan pekerjaan yang dapat meningkatkan tarap kehidupannya dengan lebih baik. Dalam upaya memberikan warga masyarakat yang membutuhkan keterampilan dan keahlian yang sangat bermanfaat sebagai sumber penghasilan serta mata pencaharian pokok sangat dipandang perlu dilaksanakan kursus dan pelatihan Keterampilan Menulis Lontar bagi warga masyarakat di Desa Tianyar Kecamatan Kubu Kab Karangasem, Bali.

Pelatihan Keterampilan Menulis Lontar merupakan peluang kerja pada masa sekarang dan yang akan datang karena merupakan salah satu sektor jasa yang tahan terhadap krisis ekonomi global. Bilamana krisis ekonomi melanda maka banyak tenaga produktif menjadi pengangguran, demikian juga banyak masyarakat yang kurang mampu khususnya anak - anak usia sekolah tidak melanjutkan pendidikannya.

Setelah diselenggarakan pelatihan keterampilan bagi warga masyarakat yang tidak bersekolah dan tidak bekerja. Dimana mereka berasal dari keluarga miskin usia 15 sampai dengan 25 tahun yang masih produktif

\section{KESIMPULAN}

Berdasarkan pelatihan yang sudah diadakan pada bulan Januari, yang melibatkan 10 Warga belajar dari desa Tunassari diperoleh hasil yang cukup memuaskan karena diantara 10 Warga belajar yang diberikan pelatihan hanya 4 orang yang belum berkompeten menulis lontar, karena terbatasnya kemampuan warga dalam menyerap materi yang diberikan. Adapun beberapa masalah yang dijumpai saat pelatihan sampai dengan selesainya program adalah 1) Terbatasnya modal, 2) kurangnya sarana dan prasarana penunjang, 3) Kurangnya tenaga ahli yang profesional, 4) Kurang sosialisasi dari pihak terkait, 5) dan permasalahan yang lain yang sekiranya kurang mendukung program. Sedangkan untuk solusi yang ditawarkan adalah masyarakat akan diberikan pelatihan berkelanjutan guna mengatasi permasalahan yang ada serta akan dibantu dari segi pemasaran dengan membuatkan blog pemasaran. Sehingga 
kendala-kendala yang ada dapat di minimalisir.

DAMPAK DAN MANFAAT KEGIATAN

Adapun manfaat yang diperoleh dari penyelenggaraan $\mathrm{PKH}$ baik bagi kelompokmaupun bagi warga belajar adalah sebagai berikut :

1. Membantu masyarakat yang kurang mampu secara ekonomi, menganggur, usia produktif dan putus sekolah/tamat tidak melanjutkan untuk memiliki keterampilan yang sesuai dengan kebutuhan dunia usaha dan industri.

2. Dengan bekal keterampilan yang telah dimiliki peserta didik, sebagai bekal memasuki dunia kerja yang dapat memberikan manfaat dan berguna dalam meningkatkan taraf hidupnya.

3. Implementasi program $\mathrm{PKH}$ ini diharapkan hasilnya benar-benar dapat menurunkan atau mengurangi jumlah pengangguran yang terjadi dimasyarakat.

4. Mengembangkan sentra-sentra unit usaha yang berbasis pada potensi dan kearifan lokal yang terintegrasi dalam dimensi sosial, budaya dan lingkungan.

\section{DAFTAR PUSTAKA}

Burns, P. and J. Dewhurst. 1996. Small Business and Enterpreneurship

James Stoner. 1995. Management, 1995. Management. Prentice Hall Inc, New Jersey

Nurul Indarti. Entrepreneurship dan Usaha Kecil \& Menengah di Indonesia

Peter Drucker. The Leadership of the Future. Penerbit PT. Elex Media Komputindo.

Deborah Tannen, 1996, Seni komunikasi Efektif: membangun relasi dengan membina gaya percakapan, (alih bahasa dra. Amitya Komara), PT Gramedia Pustaka Utama, Jakarta.

Joseph A. Devito,1997, Komunikasi antar manusia (edisi kelima), Profesional Books, Jakarta.
Prof. Dr. Astrid S. Susanto-Sunarto, 1995, Globalisasi dan komunikasi, Pustaka Sinar Harapan, Jakarta.

R. Wayne Pace, Don F. Faulos, 2002, Komunikasi Organisasi: Strategi meningkatkan kinerja perusahaan (editor Deddy Mulyana, MA, Ph.D.), PT Remaja Rosdakarya, Bandung. 